\title{
Range Improvements, Economics, and
}

\section{Financially Marginal Ranching Units-}

\section{A Perspective}

\author{
MICHAEL D. PITT AND WILLIAM A. KERR
}

Highlight: Reseeding of spring ranges, development of wet meadows, and direct income transfers were compared as potential methods for maintaining financially marginal ranching units. Selection of the most appropriate method varied with decisionmaking levels, as society, governmental agencies, and individual firms all possess different evaluative criteria. If society wishes to encourage the ranching community and to increase rangeland productivity, then economists and biologists must combine their efforts to ensure that these two-fold objectives are achieved with a least-cost alternative.

At the 27th annual meeting of the Society for Range Management in Tucson, Arizona, federal agricultural officials from both Canada and the United States stressed the growing demand for beef throughout North America (Long 1974, Whelan 1974). These optimistic predictions, which assume that past trends in beef consumption will continue into the future, are based on expectations of increasing population and larger per capita income (Upchurch 1967) combined with the comparatively high income elasticity for beef (Hassan and Johnson 1976). Such trends, in concert with the relative price inelasticity of beef (Workman et al. 1972), should provide for a healthy and expanding livestock industry.

However, even though demand for beef and other rangeland products remains strong, financial returns to the ranching community remain low. North American cattle prices are not substantially different today than they were following World War II, even though costs have increased dramatically (Tidwell 1977). Tidwell lamented that "approximately one half the cost of retail beef today goes to the rancher, feeder, and packer for the production and costs of the first two years of a steer's life, while the latter one-half of the cost is incurred in the final few days prior to the consumer's purchase at the meat counter." Saunderson (1973) concluded that ranchers face an uphill battle in making an adequate family income, and are able to stay in business primarily because of artifically low interest rates on borrowed capital, and appreciation of the home ranch in conjunction with subdivision of lands historically used for grazing purposes. Ability to stay in business can also be attributed to rancher's acceptance of low income and return on investment.

Authors are assistant professor of range ecology, Department of Plant Science University of British Columbia, Vancouver, B.C., Canada V6T I W5; and PhD candidate, Agricultural Economics, Department of Agricultural Economics, University of British Columbia, Vancouver.

Manuscript received August 8, 1977.
Obviously, the ranching community currently contends with severe economic problems as it seeks to achieve adequate financial returns to investments, including rangeland improvement projects. Range managers have learned much about making grazing lands more productive but must also acknowledge the fact that most of these lands have a relatively low capacity to absorb inputs profitably (Upchurch 1967). Leistritz and Qualey (1975) illustrated the fact that fertilization of native rangeland in the Northern Great Plains was not a profitable enterprise. Workman and Quigley (1974), investigating six Utah range and meadow sites, found that nitrogen fertilization was profitable when forage was harvested as hay, but was unprofitable when forage was harvested by grazing animals. Such "negative" economic conclusions concerning rangeland improvements have created a Malthusian-like reputation for rangeland economics. Consequently, economists are often criticized for applying economic criteria to what are considered biological, ecological, or social problems. Critics often cite the extra-market benefits of rangeland resources as a justification why economic analyses may not be able to solve rangeland management problems. However, such an attitude represents a misunderstanding of economic science, and a possible failure on the part of both economists and biologists to communicate to each other their respective needs and objectives. Economists seek to optimize returns to biological rangeland improvements by delimiting the area of possible alternatives and the probable outcome of different actions (Hooper 1967). To describe these optimal returns, economists must have access to biological data that adequately quantify all possible alternatives and outcomes. Only if such data exist can economic analyses quantitatively evaluate extra-market benefits of rangeland improvements. For example, Heady and Bartolome (1977) determined that costs of the Vale rangeland rehabilitation program, at current AUM fees, exceeded market benefits by approximately $\$ 5$ million. However, these investigators concluded that nonmarket values of the Vale program, including restoration of abused natural resources, exceeded this $\$ 5$ million figure, thereby "economically" justifying the Vale project. Similarly, Workman and Hooper (1968) evaluated financial returns of projects in mountain rangelands of Utah, and stressed the importance to society of other extramarket rangeland benefits, such as financial stability of local ranching communities and continuation of a domestic, locally produced beef supply. To ignore these extra-market benefits of rangelands when rejecting or advocating range- 
land improvements represents an error of omission, but does not imply that economics is an inappropriate tool to evaluate biological goals. Rather than criticizing the science of economics for these omissions of data, everyone concerned with rangelands should strive to provide the type and amount of information necessary to produce complete and useful economic analyses.

\section{Decision Criteria}

When making rangeland improvement decisions, society, governmental agencies, and individual firms all face different constraints. Society determines its preferences partly on socioeconomic criteria and partly on biological criteria. Within these publically determined preferences, governmental agencies initiate projects subject to political and budgetary constraints as well as economic and biological information. However, immediate ranch survival is often based upon the criterion of short-run profit maximization, where profit $(Q)=$ total revenue $(T R)$ - total cost $(T C)$. In more specific terms,

$$
\mathrm{Q}=\mathrm{P}_{\mathrm{y}} \mathrm{Y}-\sum_{\mathrm{i}=1}^{\mathrm{n}} \mathbf{P}_{\mathrm{i}} \mathrm{X}_{\mathrm{i}}
$$

where $P_{\mathrm{y}}, Y, P_{\mathrm{i}}$ and $X_{\mathrm{i}}$ are price of livestock, number of livestock, prices of inputs, and inputs to production, respectively. Given a production function of the form $Y=f\left(X_{\mathrm{i}}----X_{\mathrm{n}}\right)$, maximum profit is obtained at that level of livetock production, subject to the usual second order conditions, where the set of $n$ equations for $d Q / d X_{1}$, is equal to 0 . However, this optimum level of livestock production is determined primarily in terms of current prices, and does not guarantee that forage will be utilized at stocking rates consistent with continued productivity of the rangeland resourse. Indeed, this optimum level of livestock production may conflict with society's preferences and administrative policies. Historically, managers of publicly administered rangelands have proposed moderate stocking rates as the best means to promote recovery of depleted, as well as continued, productivity of healthy range sites (Jardine and Anderson 1919). This "least-cost alternative" of properly designed grazing systems (Fulcher 1973) advocates a small opportunity cost of unutilized forage in good years as partial insurance against the larger opportunity cost of heavy grazing, which in unfavorable growing years has the potential for subsequent range deterioration (Hooper and Heady 1970). Unfortunately, these biological criteria do not adequately determine either the "best" moderate stocking rate that would provide for optimal health of rangeland or optimal financial returns to individual ranch units.

Pearson (1973) defined such an optimum stocking rate for maximum profit on ponderosa pine (Pinus ponderosa) range in Arizona. By setting marginal revenue equal to marginal cost, Pearson determined optimum stocking rates to be $54 \%$ forage utilization in areas producing $500 \mathrm{lb}$ per acre $(560 \mathrm{~kg} / \mathrm{ha})$, and $38 \%$ utilization of forage producing $1,000 \mathrm{lb}$ per acre $(1,120 \mathrm{~kg} / \mathrm{ha})$. Both of these stocking rates represent moderate grazing intensities, and, therefore, constitute appropriate grazing recomendations. However, if this procedure had produced an optimum stocking rate utilizing perhaps as much as $80 \%$ of the available forage, then the criterion of profit maximization would be inconsistent with moderate grazing levels. Therefore, moderate grazing intensity, which represents a biological constraint, must be incorporated into the profit maximization function before determining stocking rates. If the biological constraint is binding, livestock numbers and therefore income would be reduced below levels suggested by $80 \%$ utilization.

Woodworth (1973) analyzed the distribution of a cattle herd between two ranges in Oregon utilizing the criterion of profit maximization, while at the same time ensuring that neither range became overgrazed. Using a similar technique to that of Pearson, Woodworth obtained an optimum cattle distribution by inserting biological constraints into the profit function prior to solving for the first derivative. These constraints, which limited the total number of animals that could be placed upon the two ranges, ensured that the recommended stocking rate would not exceed proper grazing intensity.

It is entirely possible, however, that long term profits could be maximized, that the continued health of the range could be maintained, and that total ranch revenue in poor years would be less than adequate for the rancher to remain in business. Consequently, in addition to biological constraints, the profit maximization formula must include constraints that define the rancher's requirement for minimum net revenue during each year of operation. Whitson (1975) provided such a solution for assessing different management plans in the Rolling Plains of Texas. Fortunately, in Whitson's model, several alternatives existed that satisfied all of the biological and financial constraints. Therefore, the rancher was able to attain a fair return for his labor and investment.

Occasionally, however, the biological constraints may reduce animal unit months to the point where the rancher's income falls below his acceptable level. Such firms, according to economic theory, should leave the industry and their resources should be reallocated to more profitable opportunities. Instead, prior to 1934 and the passage of the Taylor Grazing Act, biological constraints were largely ignored by the western U.S. livestock industry, particularly on public lands. Individual operators simply ran enough animals to secure a minimum level of annual icome. Such grazing practices, with resultant range deterioration, were at least tacitly condoned by society in order to encourage settlement and development of arid western lands (Nielson 1972).

Although grazing practices are more strictly regulated than before the Taylor Grazing Act, the livestock industry may still be indirectly subsidized with AUM fees that are institutionally established below market values. Obviously where this income transfer from society to the rancher still exists, society must deem ranching to be a valuable and important way of life to maintain (Roberts 1967).

If society wishes to perpetuate the ranching industry as presently constituted, methods must be developed to maintain those marginal ranch units which are presently unprofitable. Since government has explicitly concluded that rangeland productivity must be preserved by controlling animal numbers, then some form of compensation must be available which will provide ranchers with annual incomes sufficient to remain in the ranching industry. In addition to possible subsidized grazing fees, this compensation has also taken the form of public rangeland improvement projects such as reseeding, fencing, drainage, fertilization, and brush control, which it is hoped ultimately will permit ranchers to increase animal numbers, and thus annual incomes. 
Another method society could use to maintain the ranching industry would be to provide an income supplement to cover the rancher's shortfall in annual income. Since such a direct income transfer could be perceived as a form of public aid, an independent ranching community as well as public representatives may resist such a scheme. However, if the public is to contribute to the maintenance of the ranching community, whether directly or indirectly, then the taxpayer is entitled to the highest and most efficient return to his expenditure. If consumers continue to support federal cheap food policy, direct income transfers may be the leastcost public expenditure for maintaining inefficient ranch units, particularly if minimum annual ranch income constitutes a primary goal. If other goals such as rangeland improvements, public opinion, or ranchers' sensibilities, are also deemed important, then less efficient expenditures may be employed. Certainly, however, all public expenditures must be based upon as much useful information as possible. All public strategies for maintaining ranching units, including rangeland improvements as well as income transfers, must be investigated and presented to decision-makers to evaluate in terms of society's goals. Consequently, the following discussion will compare reseeding, development of wet meadows, and direct income transfers as alternative methods for society to maintain economically marginal ranching enterprises.

\section{British Columbia Case Studies}

Numerical values used in this example are based generally upon a representative ranch for the interior of British Columbia (Graham and Sakalauskas 1975; Sakalauskas 1977). The example does not contend that ranching in interior B.C. is any more or less economical than ranching throughout North America. Rather, the example intends only to serve as a vehicle for illustrating a procedure for comparing public investments designed to maintain a ranching enterprise.

The representative ranch of southern British Columbia comprises a cow-calf-yearling operation. Some weaned calves are sold in the fall, while others are carried over the winter, ranged the following summer, and sold as long yearlings. In addition to unproductive land which includes undeveloped wet meadows, the home ranch consists of 250 acres ( $100 \mathrm{ha})$ of land producing 3 tons/acre (6.7 metric tons/ ha) of mixed hay. The feeding year is divided into four seasons: winter (October 16 - March 15); spring (March 16 May 15); summer (May 16 - August 15); and fall (August 16 October 15). Cattle are fed hay and grain in winter only, and grazed on open range the balance of the year. Crown range (publically administered land) is generally available for summer and fall grazing, but is typically limited for critical spring grazing.

The majority of British Columbia ranches support less than 100 head, although in 1966 the average full-time ranch consisted of 210 animal units (McLean 1975). Table 1 presents an abbreviated ranch income statement for an enterprise supporting a core herd of 175 animals. The net ranch income of $\$ 696$ falls approximately $\$ 3,300$ short of the $\$ 4,000$ suggested by Sakalauskas (1977) that a representative ranch family would withdraw each year for personal consumption. The ranch presented in Table I must therefore increase the size of its herd to become viable economically. Sakalauskas's representative ranch herd consists of 300
Table 1. Abbreviated ranch income based upon a ranch supporting 175 animal units in southern British Columbia.

\begin{tabular}{lrr}
\hline Item & \multicolumn{1}{c}{ Amount } \\
\hline Income: & $\$ 32,503$ & \\
$\quad$ Livestock sales & 16,500 & \\
$\quad$ Hay sales & & $\$ 49,003$ \\
Total income: & 17,236 & \\
Expenses: & 10,000 & \\
$\quad$ Crop production and feed & 19,265 & \\
$\quad$ Other livestock costs & & $\$ 46,501$ \\
$\quad$ Overhead & & 2,502 \\
Total Expenses: & & 2,264 \\
Excess of income over expenses & 4,070 \\
Add: Change in inventory & $\$ 696$ \\
Less: Depreciation & & $\$$ \\
Net farm income & & \\
\hline
\end{tabular}

cows and 16 bulls. Since many ranch herds are limited to a major extent by available forage on the spring range, as determined by the Grazing Division of the B.C. Forest Service, one possibility is to reseed these ranges to increase both productivity and carrying capacity. Carrying capacity must be increased by 433 AUM's of spring grazing to achieve a core herd size of 316 animals, which produces an increase of $\$ 3,370$ in annual income (Tables 1 and 2). The revenue derived from the sale of these animals totals $\$ 59,530$. As hay previously sold off the farm must now be used to winter feed the larger herd, total hay sales now would only realize $\$ 1,200$ (Table 2 ).

The summer herd of 714 animals requires 1,722 AUM's. An AUM costs \$.62. Therefore the total cost of summer grazing is $\$ 1,116$. Fall grazing of approximately 1,000 AUM's is required for the reduced (after sales) herd, giving a

Table 2. Abbreviated ranch income statement based upon a representative ranch supporting a basic herd of 300 cows and 16 hulls.

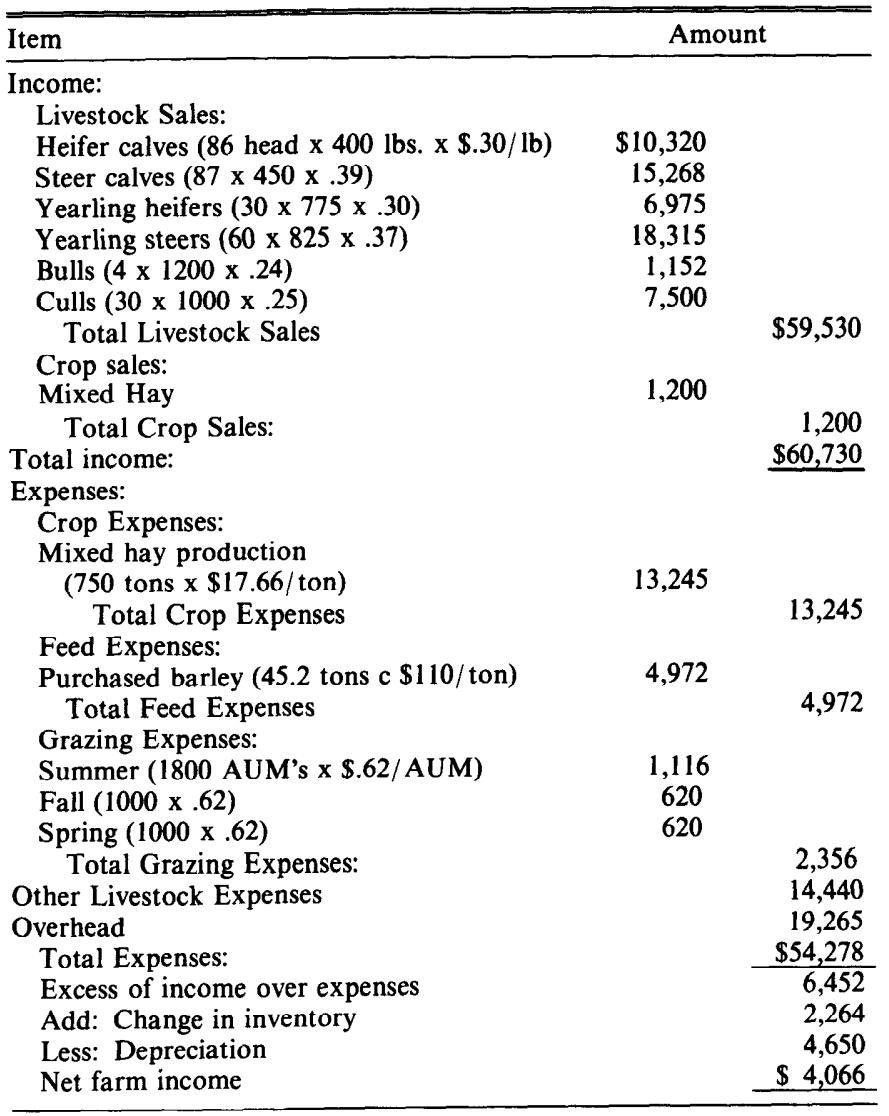


cost of $\$ 620$. Winter feeding consists of mixed hay supplemented with purchased barley. Approximately 750 tons (680 metric tons) of hay are produced on the ranch and a total of 45.2 tons (41 metric tons) of barley are required. The cost of producing hay is $\$ 17.66 /$ ton ( $\$ 16.02 /$ metric ton), giving a total cost of hay production of $\$ 13,245$. Barley is purchased at $\$ 110 /$ ton ( $\$ 99.79 /$ metric ton) for a cost of $\$ 4,972$. Therefore, total winter feeding costs equal $\$ 18,217$. Spring grazing requires approximately 1,000 AUM's at $\$ .62 /$ AUM for a cost of $\$ 620$. Total feeding costs are $\$ 20,573$. Other livestock costs are estimated at $\$ 14,440$ and overhead at $\$ 19,265$ (Sakalauskas 1977). Change in inventory equals $\$ 2,264$, while depreciation remains at $\$ 4,650$.

Reseeding of rangeland provides one alternative for attaining an additional 443 AUM's of spring grazing. Four hundred and forty-three AUM's at $600 \mathrm{lb} / \mathrm{AUM}(272.4$ $\mathrm{kg} / \mathrm{AUM}$ ) times 2 for $50 \%$ utilization, constitutes $531,000 \mathrm{lb}$ $(241,346.4 \mathrm{~kg})$ of additional required forage. Crested wheatgrass (Agropyron cristatum) yields approximately $900 \mathrm{lb}$ per acre $(1,008 \mathrm{~kg} / \mathrm{ha})$. If rangelands in poorest condition will be reseeded first, this $900 \mathrm{lb}$ per acre $(1,008 \mathrm{~kg} / \mathrm{ha})$ represents a net increase of $650 \mathrm{lb}$ per acre $(728 \mathrm{~kg} / \mathrm{ha})$ over existing poor condition native bluebunch wheatgrass (Agropyron spicatum) stands (McLean and Marchand 1968). Therefore, an increase of 443 AUM's requires that 817 acres (331 ha) be reseeded. Total seeding costs at $\$ 38.50 /$ acre $(\$ 95.13 /$ ha) (Hilton 1976) equals $\$ 31,454$. Therefore the Net Present Value (NPV) of this investment over 25 years (Gittinger 1972), assuming an annual benefit of $\$ 3,370$ equals:

$3370-31,454+\frac{3370}{1+0.10}+\frac{3370}{(1+0.10)} 2+\cdots+\frac{3370}{(1+0.10)} 24$

This equation, utilizing a $10 \%$ discount rate considered appropriate for public investment in Canada (Jenkins 1973), produces a net present value for reseeding of $\$ 2,184$. This NPV, excluding external benefits and deferment costs, indicates that seeding of spring ranges to annually increase rancher income by $\$ 3,370$, is appropriate for the individual ranch operator to undertake.

Another method often suggested to increase ranch carrying capacity in the interior of British Columbia is the development of wet meadows. These meadows could supply the hay required for the additional 443 AUM's that cannot be provided on current spring ranges. This spring grazing period is 2 months in duration; 443 AUM's represent $45 \%$ of the 976 AUM's needed to maintain the representative ranch herd through this period. In 2 months of winter feeding, 250 tons (226.8 metric tons) of hay are consumed. Forty-five percent of this is 112.5 tons (102.06 metric tons). If developed wet meadows yield 5 tons/acre ( 11.20 metric tons/ha), then approximately 22.5 acres $(9.1 \mathrm{ha})$ need to be developed.

Initial development costs of wet meadows equals approximately $\$ 250 /$ acre $(\$ 617.75 /$ ha) for a total investment of $\$ 5,625$. Following each harvest, fertilizer must be applied to these organic meadows at an annual cost of $\$ 3,262$ ( $\$ 145 /$ acre) (van Ryswyk and Bawtree 1972). This $\$ 145 /$ acre $(\$ 358.30 / \mathrm{ha})$ is based upon contracting for fertilizer, machinery, and labor, and will vary from site to site. Other annual costs to the rancher to extend his winter feeding period to maintain an increased herd, include harvesting $(\$ 1,422)$ and purchase of additional barley $(\$ 522)$. Therefore, a $\$ 3,300$ gain in total annual ranch revenue requires an additional yearly expenditure of $\$ 5,206$. These yearly costs, coupled with the initial wet meadow development price of $\$ 5,252$, produce a Net Present Value of - $\$ 24,649$ over a 25 year period.

\section{Discussion}

A negative Net Present Value does not necessarily indicate that the development of wet meadows should not be undertaken. If society is committed to raising the rancher's income by $\$ 3,300$ or whatever figure is necessary to perpetuate his home ranch, then nearly any rangeland improvement project is technically feasible. However, in purely financial terms, an income transfer is preferable to any project with a negative Net Present Value. In the case of an income transfer, the NPV is always zero, as the costs to society and the benefits (\$3,300 in both cases), cancel each other out. Therefore, based on this analysis, and without considering externalities and muliplier effects, reseeding would be preferable to wet meadow development. An income transfer would be less preferable than reseeding but more preferable than wet meadow development.

Obviously this discussion does not suggest that rangeland seeding provides the best means of maintaining economically marginal units. Rather, this discussion wishes to emphasize that economic analyses merely describe alternative modes of action and the consequences of such actions. Society, administrative agencies, and firms must still make decisions regarding which method will ultimately be used to encourage and perpetuate the ranching industry in North America. All of these decision-making units base their recommendations upon different criteria.

In the examples presented above, the Net Present Values were calculated without including externalities which may benefit society, such as restoration of natural resources, continued employment of families currently in the ranching industry, perpetuation of a locally produced beef supply, and the intrinsic value of a ranch family's self-esteem. Whatever public expenditures are required, society may wish to reseed spring ranges, develop wet meadows and provide income assurance in order to financially stimulate the ranching community. If external benefits of current rangeland improvement projects are not calculated, then one can only assume that the value of these benefits compensates the improvement costs. In this example, if wet meadows are developed, then the indirect return to society implicitly must be greater than, or equal to, $\$ 24,649$. However, to make economics more effective as a decisionmaking science, these implicit benefits should be more precisely determined so that the most efficient use of soceity's resources can be attained.

Unlike society, governmental agencies are typically unable to pursue financially unrestrained goals. All potential projects must be evaluated and ranked according to their biological and economical returns. Government officials must implement projects within agency established goals, which hopefully coincide with what are regarded as society's goals. In the above examples, reseeding provides the financially most efficient means of perpetuating marginal ranch units. If a particular ranching unit does not possess reseeding potential, then a direct income transfer becomes the next best alternative. However, if this direct income transfer is socially or politically undesirable, then wet meadow development, even with a large negative NPV, could be considered. 
In contrast to governmental agencies, all economic decisions of individual firms should be based upon long-run profit maximization to ensure ranch survival and the most efficient use of available resources. In our examples; the individual firm would choose to implement only reseeding projects with its own resources. If ranches do not command sufficient resources to provide a minimum acceptable level of income, then society must decide whether or not to supplement the ranch income. The firm itself should be indifferent to the method employed by society to guarantee ranch survival. Historically, however, the ranch community has not welcomed direct income transfers. Therefore, if society wishes to achieve the multiple goals of respect for rancher sensibilities, financial stability, and biological productivity, then another alternative must be selected. Only by working together can economists and biologists provide the information necessary for society to select the best alternative.

Economists can document financial costs and returns based upon biological costs and returns of rangeland improvement projects. Indeed, economists and biologists should harbour the same objectives, and consequently, seek the same information to achieve these objectives. All those rangeland resource managers, who seek to optimize returns to the ranching community, also wish to enhance rangeland productivity. Therefore, society's decision-makers, economists, and biologists all require specific information on the ecological and financial resources of ranchers, utilization rates of livestock, the impact of these utilization rates on rangeland plants and soils, feeding requirements of livestock, production rates of livestock, lifespan of improvement projects, and a host of other basic factors upon which good range management depends. It must be realized, however, that the science of economics is neither wrong nor inappropriate when it arrives at uneconomic returns for range management projects. Instead, those concerned primarily with rangeland biology should aid economists in providing the information needed by decision-makers to transmit correctly the preferences of society into action. If society shows a preference for maintaining the ranching community as well as to increase and/or rehabilitate rangeland productivity, then economists and biologists must wed their efforts to ensure that society achieves these two-fold objectives with a least-cost alternative.

\section{Literature Cited}

Fulcher, G. F. 1973. Grazing systems: A least cost alternative to proper management of the public lands. J. Range Manage. 26:385-87.

Gittinger, J. P. 1972. Economic analysis of agricultural projects. Baltimore. The John Hopkins Press.

Graham, J. D., and A. J. Sakalauskus. 1975. CFAB, A computerized farm analysis package for beef ranches. Dep. Agr. Econ. Univ. British Columbia. $224 \mathrm{p}$.

Hassan, Z. A., and S. R. Johnson. 1976. Consumer demand for major foods in Canada. Agr. Canada, Econ. Branch. Pub. 76.2.

Heady, H. F., and J. W. Bartolome. 1977. The Vale rangeland rehabilitation program: The desert repaired in southeastern Oregon. U.S. Dep. Agr. Forest Serv. Resour. Bull. PNW-70. 139 p.

Hilton, J. 1976. Personal communication.

Hooper, J. F. 1967. Potential for increases in grazing fees. J. Range Manage. 20:300-304.

Hooper, J. F., and H.F. Heady. 1970. An economic analysis of optimum rates of grazing in the California annual-type grassland. J. Range Manage. 23:307-311.

Jardine, J. T., and M. Anderson. 1919. Range management on the national forests. U.S. Dep. Agr. Bull. 790.98 p.

Jenkins, G. P. 1973. The measurement of rates of return and taxation from private capital in Canada. In: Benefit cost and policy analysis, 1972. Chicago Aldine Publishing Co. 535 p.

Leistritz, F. L., and N. J. Qualey. 1975. Economics of ranch management alternatives in southwestern North Dakota. J. Range Manage. 28: 349-352.

Long, R. W. 1974. Future of rangelands in the United States. J. Range Manage. 27:253-255.

McLean, A. 1975. Range management report. Environment and Land Use Committee. Min. Lands, Forests, Water Resources. Victoria, B.C. mimeo., $74 \mathrm{p}$.

McLean, A. and L. Marchand. 1968. Grassland ranges in the southern interior of British Columbia. Agr. Canada Pub. 1319. 28 p.

Nielson, D. B. 1972. Economic implications of variable versus single grazing fees. J. Range Manage. 25:2-6.

Pearson, H. A. 1973. Calculating grazing intensity for maximum profit on ponderosa pine range in northern Arizona. J. Range Manage. 26: 277-278.

Roberts, N. K. 1967. Discovering grazing values. J. Range Manage. 20: 369-375.

Sakalauska, A. J. 1977. A computerized farm management information system for commercial beef ranch operations. Unpub. M.Sc. Thesis, Univ. British Columbia. 231 p.

Saunderson, M. H. 1973. Trends in western ranch prices and values. J. Range Manage. 26:6-9.

Tidwell, J. M. 1977. Facts and myths: An answer. Rangeman's J. 4:22.

Upchurch, M. L. 1967. Rangelands - Challenge to the pocketbook. J. Range Manage. 20:284-287.

van Ryswyk, A. L., and A. H. Bawtree. 1972. Management and improvement of meadows on organic soils of interior British Columbia.B.C. D.A. Field Crops Branch, Pub. 72-3. 11 p.

Whelan, E. F. 1974. Future of rangelands in Canada. J. Range Manage. 27:256-257.

Whitson, R. E. 1975. Ranch decision-making under uncertainty-An illustration. J. Range Manage. 28:267-270.

Woodworth, B.M.1973. Optimizing the calf mix on range lands with linear programming. J. Range Manage. 26:175-176.

Workman, J. P., and J. F. Hooper. 1968. Preliminary economic evaluation of cattle distribution practices on mountain rangelands. J. Range Manage. 21:301-304.

Workman, J. P., S. L. King, and J. F. Hooper. 1972. Price elasticity of demand for beef and range improvement decisions. J. Range Manage. 25:338-341

Workman, J. P., and T. M. Quigley. 1974. Economics of fertilizer application on range and meadow sites in Utah. J. Range Manage. 27:390-393. 